\title{
The Effect of Consumer Self-Brand Connection on Willingness to Buy Luxury Brand Counterfeit
}

\author{
Khalima Hema Suya \\ School of Management, Shanghai University \\ 99 Shangda Road, BaoShan District, Shanghai
}

\begin{abstract}
Consumer self-brand connection further conceptualized as a consumer's positively balanced brand-related cognitive, emotional and behavioral activity during or related to focal consumer/brand interactions. Brands have the ability to both influence customer purchase decisions as well as shape consumer identities. The results of consumer self-connection to brand made them loyal enough to buy originals luxury products. While research in both these respective areas provides some solid insight into how consumers view original luxury goods and counterfeits, there are still convinced questions that are ignored therefore left unanswered to truly integrate these streams. Our study first integrates and extend recent research in both areas by first exploring if consumers buy LBC products to fulfill certain psychological needs such as the ability to construct and/or reflect their selfconcept (or image) to others using their self-brand connection. Therefore, we investigated the effect of customer's self-brand connection on their willingness to buy luxury counterfeit products.
\end{abstract}

Keywords: Conspicuous product consumption; Consumer self-brand connection; Luxury brand counterfeit; Emotional attachment

DOI: $10.7176 / \mathrm{JMCR} / 73-03$

Publication date: November $30^{\text {th }} 2020$

\section{Introduction}

Consumer self-brand connection has been described in the literature as the extent to which a consumer has incorporated a brand into his or her self-concept (Escalas, 2004; Escalas and Bettman, 2003; 2005). Thus, CSBC construct one's self or to communicate one's self to others. While the self-concept defined as "totality of the individual's thoughts and feelings having reference to himself as an object" (Rosenbaum et al., 2011). More recently the consumer self-brand connection (CSBC) concept has been postulated to more comprehensively reflect the nature of consumers' particular interactive brand relationships, relative to traditional concepts, including 'involvement. CSBC is claimed to come out of consumer brand love. Whereby, brand love is composed of three second-order factors: passion-driven behaviors, self-brand integration, and positive emotional connection (Kwon and Mattila, 2015; Batra et al., 2012). Consumer self-brand connections are stronger in public consumption situations than those in private ones which reflect need for achievement in a public consumption situation (Huang and Mitchel, 2013). Construction of self has been claimed in the literature as the reason which makes consumers connected to brand (Park et al., 2008). Some researcher argued that self-brand connection can be as a result of individual characteristics such as need for achievement (Huang and Mitchel, 2013) and consumers' ability to decode and encode brand meanings (Escalas and Bettman, 2005) which comes from their sensitivity to brand information. Strong brands are endowed with salient symbolic meanings, which attract consumers in order to satisfy their social desirability and acceptance needs by the possessions of these brands (Kircova et al., 2015). Different reasons such as celebrity endorsement (Dwivedi et al., 2015), and self-identities or desired self-images thus improve or reinforce the self (Escalas and Bettman, 2003) have been mentioned in prior studies for a consumer to connect with the brand. However, the connection of consumers to brand which lead a consumer to buy original products has received attention than the connection of consumer to brand which lead a consumer to buy LBC

\section{Literature Review \\ 2.1 consumer self-brand connection concept.}

We define consumer self-brand connection as the extent to which a consumer has incorporated a brand into his or her self-concept (Escalas and Bettman, 2003). Specifically, more recently the 'consumer self-brand connection' (CSBC) concept has been postulated to more comprehensively reflect the nature of consumers' particular interactive brand relationships, relative to traditional concepts, including 'involvement.' CSBC further conceptualized as a consumer's positively balanced brand-related cognitive, emotional and behavioral activity during or related to focal consumer/brand interactions (Hollebeek et al., 2014). Brands have the ability to both influence customer purchase decisions as well as shape consumer identities.

\section{2 conspicuous product consumption.}

Conspicuous product consumption states to consumers' desire to provide prominent visible evidence of their 
ability to afford luxury goods (Wang and Griskevicius, 2013). Motivated by a desire to impress others with their ability to pay particularly high prices for prestige products, conspicuous consumers may be inspired by the social rather than the economic or physiological utility of merchandise (Phillips and Back, 2011). CPC is not limited to the leisure class but can be available in all social and income groups from richest to poorest. By advertising their wealth, people who engage in CPC thereby achieve greater social status (Bagwell and Bernheim, 1996). Conspicuous products are not intrinsically superior to budget brands but are purchased by consumers who seek to signal high levels of wealth (Bagwell and Bernheim, 1992). Researchers and marketers generally accept that the product's conspicuousness is important in consumer decision making (Piron, 2000). An increasing number of customers have the potential to become purchasers of conspicuous products/services that display their exalted social status and enhance their self-image in that exhibiting one's wealth, achievement, or success (Piron, 2000).

\subsection{The willingness to purchase l luxury brand counterfeit.}

The customer desire for luxury brands is not accomplished due to the lack of affordability to exorbitant price tags of original luxury brands (Nia and Lynne Zaichkowsky, 2000). This may be caused by extremely unjust and the large gap between the rich and the poor in the world as it has been reported from the World Bank. Consumers such as Chinese in particular behave more irrationally in luxury purchase because luxury brands are something "must to have" for them to reinforce their social status. For example, the study by Jiang and Cova (2012) found out that consumers believe it's fun and enjoyable to purchase and consume illegal brands which raise their willingness to purchase LBC. Besides, the counterfeit manufacturer claim that their production are satisfying the demand of those consumers who unable or unwilling to pay for the originals (Lai and Zaichkowsky, 1999), and because of the consumers 'desire for real luxury brands, the literature has reported their willingness to purchase LBC

\subsection{Emotional Attachment}

Attachment has been defined as an emotion-laden, target-specific bond between a person and a specific object (Bowlby, 1979). Stronger attachments are associated with stronger feelings of affection, love, and passion (Thomson et al., 2005). Thomson, MacInnis, and Whan (2005) and Thomson et al. (2005) measured the strength of consumers 'emotional attachments to brands and identified three first order factors: affection (affectionate, friendly, loved, peaceful), passion (passionate, delighted, captivated), and connection (connected, bonded, attached). The study by Bowlby (1979) described that the degree of emotional attachment to an object predicts the nature of an individual's interaction with the object. Thus, individuals who are strongly attached to a person are very likely to be committed to, invest in, and make a lot of sacrifices for that person. EA binds the customer to the brand, producing desire-driven persistence. EA is a significant determinant of loyal behavior (Giraffe and Nguyen, 2011). In this study, we argue that emotional attachment is a psychological mechanism that explains the willingness to buy LBC and as a moderating factor in the relationship between emotional attachment and the willingness to buy LBC.

\section{Theoretical Model and Hypothesis.}

The study proposed theoretical model shown below. This model depicts causal relationships between the variables First it shows that the Consumer self-brand connection (CSBC), Conspicuous product consumption (CPC) and Emotional attachment (EA) were directly affected the willingness to buy LBC. Moreover, CPC and EA are moderators between CSBC and the willingness to purchase LBC Also, CPC and EA acted as moderators in the relationship between $\mathrm{CSBC}$ and the willingness to buy LBC

\section{1 consumer Self-Brand connection and willingness to buy Luxury Counterfeit-Product}

Consumer self-brand connection is not based on such inconsistency between user image and brand image; instead it incorporates the degree to which a given brand gets incorporated into the self-concept. Different reasons are described in literature as the source of consumer brand connection. The reason such as celebrity endorsement of a certain brand convincing consumers to easily connected to those brands (Dwivedi et al., 2015). For example, in the USA, celebrity endorsements are a popular advertising strategy, representing approximately 15 per cent of advertisements (Crutchfield, 2010). When a brand is connected with a celebrity through an endorsement arrangement, associative links among nodes are formed in consumer memory retention. The difference in price between the original and the counterfeit product likely has a strong main effect on consumers' intention to consider the counterfeit. This may occur when consumer has no feeling to support the original company which manufactured the product (Poddar et al., 2012). The study by Kaufmann et al. (2016a) suggested that some people are attached with the appearance of legitimate goods (whether for the brand or its appearance) and have no use for the actual, legitimate product and therefore ended up purchasing counterfeit product of the same brand. This explanation suggested the following hypothesis.

H1: Consumer self-brand connection has a positive effect on the willingness to buy LB 


\subsection{Emotional Attachment and Willingness to Buy LBC}

Emotional attachment is a significant determinant of loyal behavior (Grisaffe and Nguyen, 2011). EA suggested being one of the decisional factors driving consumer to buy counterfeit products when consumer feels its selfconcept is compromised. Emotional attachment described as an emotion-laden, target-specific tie between a person and a specific object (Bowlby, 1979). Although consumers interact with thousands of products and brands in their lives, they develop an intense emotional attachment to only a small subset of these objects. The study by Bowlby (1979) described that the degree of emotional attachment to an object predicts the nature of an individual's interaction with the object. Thus, the consumers may appear unhappy about being unable to purchase the original brand of their choice but may appear happy when they find out that it can be replaced by the counterfeit luxury brand (Gistri et al., 2009). Therefore, based on this explanation, one may suggest EA to be a valid measure of emotional attachment should predict consumers' commitment to a brand, such as their loyalty to that brand. Therefore, based on this the article makes the following assumptions:

H2: Emotional attachment has a positive effect on the willingness to buy LBC.

\subsection{Emotional Attachment as Moderator.}

A moderator is a variable that alters the direction or strength of the relation between a predictor and an outcome (Baron and Kenny, 1986). Thus, the moderator variable can cause the relationship in question to either strengthening, change or weakening. The study by Penz and Stöttinger (2012) found out that emotional attachment motivates consumers to take actions that assist them to achieve their goals of owning a LBC. This may strengthen the connection they have to brand and buy LBC of their choice. The strength of emotional attachment to an object may be associated with investment.in the object, that is, the willingness to forego immediate self-interest to promote a relationship (Van Lange et al., 1997). Therefore, during the intention process which involve emotion, consumers balance counterfeit benefits against monetary costs and make intention to buy LBC (Penz and Stöttinger, 2012) the involvement of emotional attachment was found by Gistri et al. (2009) that the respondents showed an emotional reaction to counterfeit luxury brand. They display emotionally how unhappy was for them to not be able to purchase the original. But after found out that they can also access the counterfeit which was similar to original one, their happiness rouse. This reaction from consumers may enhance their brand connection and their willingness to purchase LBC. This leads to the following hypothesis:

H3: Emotional attachment positively moderates the relationship between consumer self-brand connection and the willingness to buy LBC.

\subsection{Conspicuous Product Consumption and Willingness to Purchase LBC}

The significant growth of conspicuous goods (luxury) consumption in recent decades has been accompanied by a prevalence of pirated and counterfeited goods (Wiedmann et al., 2012). Suppliers of counterfeits argue that their actions are satisfying the demand of people who strive to own status-laden brands without being able or willing to pay for the original (Wilke and Zaichkowsky, 1999). More likely, this means that as the demand for a certain brand increases, the consumer willing to buy LBC may increase as well. This leads to the following hypothesis:

H4: Conspicuous product consumption tendency has a positive effect on willingness to buy LBC

\subsection{Conspicuous Product Consumption as a Moderator.}

The moderating role of CPC was seen in the study Wang and Chen (2004) whereby, the CPC moderated the relationship between customers' belief of a product appropriateness and willingness to buy. This show that consumers can choose the brand based on CPC (O'Cass and Frost, 2002). Study done by Wang and Liu (2007) found the moderating effect of CPC between product performance and customer satisfaction. (Wang and Griskevicius, 2013). These studies proved that the consumption of goods with conspicuous consumption are made for short term investment value, undertaking for the purpose of securing prompt gains in status and prestige (Wang and Griskevicius, 2013). As the performance of brand play high importance but consumers aimed for the low investment, consumers may involve more in LBC and therefore strengthening the relationship between CSBC and willingness to purchase LBC. The aforementioned understanding lead to the following hypothesis:

H5: Conspicuous product consumption tendency positively moderates the relationship between consumers self-brand connection and the willingness to buy LBC. 


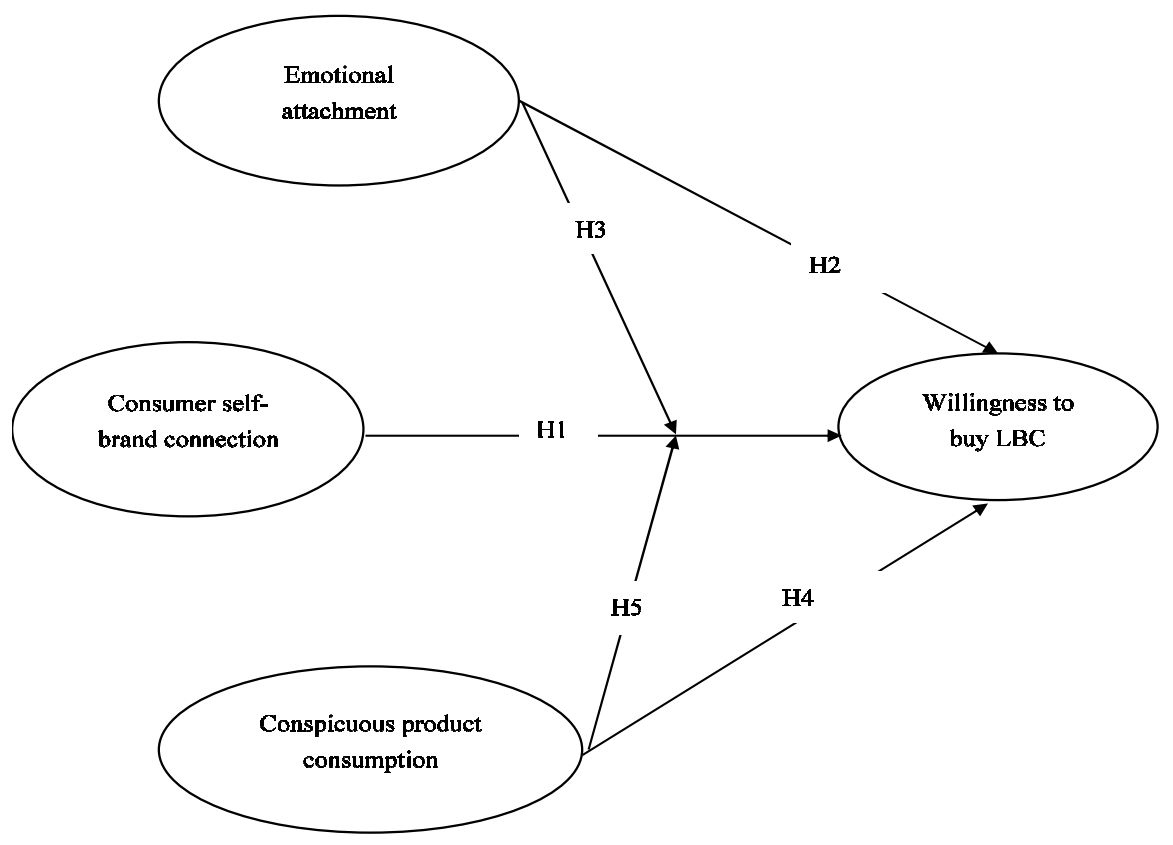

Figure 1 Theoretical Model

\section{Research Methodology}

4.1 Data Collection and Sample Size

This study used cross- sectional survey design in collecting data whereby foreign students who are working and studying in china were selected. The questionnaires were distributed to foreigners located in shanghai using online link .a total number of 450 were selected. Statistical package (SPSS) and Analysis of a moment structure (AMOS) for Analyzing Data.

Table 1 Sample characteristics $(\mathbf{N}=\mathbf{4 5 0})$

\begin{tabular}{lll}
\hline & Frequency & $\%$ \\
\hline Gender & 212 & 47 \\
Male & 238 & 53 \\
Female & & \\
\hline Education & 180 & 40 \\
Masters & 270 & 60 \\
Bachelors & & \\
\hline Age & 76 & 17 \\
Below 20 years old & 124 & 28 \\
20 to 30 years old & 156 & 35 \\
30 to 45 years old & 94 & 21 \\
Above 45 years old & & \\
\hline Monthly income $(\boldsymbol{R M B})$ & 63 & 14 \\
25,000-15,000 & 179 & 40 \\
14,000-5000 & 208 & 46 \\
$<5000$ & & \\
\hline
\end{tabular}

5.1 Reliability and Validity Measures

The study first checked each construct and values of Cronbach's alpha were above 0.7 cutoff levels as suggested by Hair et al. (2013). Using CFA, the study found acceptable model fit $\mathrm{X}^{2}=470.056, \mathrm{df}=237$, RMSEA $=0.046$, $\mathrm{CFI}=0.967$, SRMR $=0.035$. Average variance extracted (AVE) values ranged between 0.51 and 0.60 . Higher AVE scores indicate that a latent construct explains more of the variance in its item measures than the proportion of variance it shares with other constructs (Jackson, 2003). Construct reliability of measurements models ranged between 0.71 and 0.91 Reliability (Alpha) values ranged between 0.70 and 0.90 . According to the recommended range by Hair et al. (2013) that AVE should be higher than 0.5 and construct reliability should be higher than 0.7 , therefore, the measurement model's convergent validity is acceptable 
Table 2 Descriptive Analysis (Correlation, Means and Standard Deviation)

\begin{tabular}{|c|c|c|c|c|c|c|c|c|c|c|c|}
\hline Variable & $\mathbf{M}$ & SD & 1 & 2 & 3 & 4 & 5 & 6 & 7 & 8 & 9 \\
\hline Age & $\mathrm{n} / \mathrm{a}$ & $\mathrm{n} / \mathrm{a}$ & 1.00 & & & & & & & & \\
\hline Gender & $\mathrm{n} / \mathrm{a}$ & $\mathrm{n} / \mathrm{a}$ & 0.003 & 1.00 & & & & & & & \\
\hline Aff. & 3.41 & 0.65 & $0.110 *$ & $0.270 * *$ & 1.00 & & & & & & \\
\hline Prior & 4.02 & 0.64 & -0.036 & -0.013 & 0.056 & 1.00 & & & & & \\
\hline Auth. & 2.31 & 0.81 & -0.007 & 0.012 & 0.064 & $0.240 * *$ & 1.00 & & & & \\
\hline CSBC & 3.75 & 0.58 & -0.024 & -0.067 & 0.099 & $0.540 * *$ & $0.230 * *$ & 1.00 & & & \\
\hline EA & 3.75 & 0.53 & -0.054 & 0.051 & 0.07 & $0.320 * *$ & $0.280 * *$ & $0.630 * *$ & 1.00 & & \\
\hline LBC & 3.28 & 0.67 & 0.02 & -0.029 & $0.470 *$ & $0.160 * *$ & $0.660 * *$ & $0.530 *$ & $0.160 * *$ & 1.00 & \\
\hline CPC & 3.56 & 0.78 & -0.085 & -0.019 & $0.20^{*}$ & $0.470 * *$ & $0.240 * *$ & $0.550 * *$ & $0.650 * *$ & $0.350 *$ & 1.00 \\
\hline
\end{tabular}

Note: $N=450, p^{*<0.05} p^{* *<0.01(T w o ~ t a i l e d) . ~ E A=E m o t i o n a l ~ A t t a c h m e n t, ~ C P C=C o n s p i c u o u s ~ P r o d u c t ~}$ Consumption; $C S B C=$ Consumer Self-Brand Connection; $L B C=$ Luxury brand counterfeit, Aff. $=$ Affordability, Prior $=$ Prior fake product experience, Auth. $=$ Authentic Products.

Table 1 Reliability and Validity Measures

\begin{tabular}{|c|c|c|c|c|c|}
\hline Construct & $\begin{array}{l}\text { Factor } \\
\text { loadings }\end{array}$ & Items & $\alpha$ & $\mathbf{C R}$ & AVE \\
\hline & & $\begin{array}{l}\text { Consumer self-brand connection -Escalas and Bettman } \\
(2003)\end{array}$ & \multirow[t]{6}{*}{0.90} & \multirow[t]{6}{*}{0.91} & \multirow[t]{6}{*}{0.53} \\
\hline CSBC1 & 0.52 & The luxury brand reflects who I am. & & & \\
\hline $\mathrm{CSBC} 2$ & 0.70 & I can identify with the luxury brand & & & \\
\hline CSBC3 & 0.80 & I feel a personal connection to the luxury brand & & & \\
\hline CSBC4 & 0.76 & $\begin{array}{l}\text { I (can) use this luxury brand to communicate who I am to } \\
\text { other people. }\end{array}$ & & & \\
\hline \multirow[t]{2}{*}{ CSBC5 } & 0.87 & I consider this luxury brand to be "me". & & & \\
\hline & & Conspicuous product consumption- Marcoux et al., (1997) & \multirow[t]{7}{*}{0.85} & \multirow[t]{7}{*}{0.91} & \multirow[t]{7}{*}{0.60} \\
\hline $\mathrm{CPC} 1$ & 0.71 & Noticed by others & & & \\
\hline $\mathrm{CPC} 2$ & 0.87 & Presence of others & & & \\
\hline CPC3 & 0.85 & Gain respect & & & \\
\hline CPC4 & 0.75 & Popularity & & & \\
\hline CPC5 & 0.74 & Show who I am & & & \\
\hline \multirow[t]{2}{*}{ СPC6 } & 0.55 & Seen using it & & & \\
\hline & & Willingness to buy-Dodds, Monroe, and Grewal (1991) & \multirow[t]{5}{*}{0.76} & \multirow[t]{5}{*}{0.77} & \multirow[t]{5}{*}{0.53} \\
\hline WTB1 & 0.86 & The likelihood of purchasing this product & & & \\
\hline WTB2 & 0.89 & The probability that I would consider buying the product & & & \\
\hline WTB3 & 0.85 & I intent to buy this product. & & & \\
\hline \multirow[t]{2}{*}{ WTB4 } & 0.82 & At this price shown, I would consider buying the product. & & & \\
\hline & & $\begin{array}{l}\text { Emotional Attachment -Thomson, MacInnis, and Whan } \\
\text { Park (2005) }\end{array}$ & \multirow[t]{11}{*}{0.70} & \multirow[t]{11}{*}{0.71} & \multirow[t]{11}{*}{0.51} \\
\hline EA1 & 0.71 & Affectionate & & & \\
\hline EA2 & 0.83 & Friendly & & & \\
\hline EA3 & 0.64 & Loved & & & \\
\hline EA4 & 0.72 & Peaceful & & & \\
\hline EA5 & 0.88 & Passionate & & & \\
\hline EA6 & 0.66 & Delighted & & & \\
\hline EA7 & 0.87 & Captivated & & & \\
\hline EA8 & 0.93 & Connected & & & \\
\hline EA9 & 0.85 & Bonded & & & \\
\hline EA10 & 0.72 & Attached & & & \\
\hline
\end{tabular}

Note: $C S B C=$ Consumer self-brand connection; $C P C=$ Conspicuous product consumption; $W T B=$ Willingness to buy $L B C ; E A=$ Emotional attachment

\section{Results}

4.1 Hypothesis testing

We used the structural equation model (SEM) technique with the maximum likelihood estimation to test the proposed hypothesis in alignment with the study by Podoshen and Andrzejewski (2012) and Yadav and Pathak 
(2016). Assessment of the model follows the recommended two-step approach to structural equation modeling (SEM) that separates the measurement model from the structural model. The measurement model defines the relationship between our observed variables and their unobserved, latent constructs while the SEM model defines the relationship between our latent constructs. Because the sample size is large, multiple fit indices were used to assess the overall fit of the model (Hair et al., 2013). The structural equation model as implemented in AMOS, testing the predicted relationships among CSBC, conspicuous product consumption, Emotional attachment and the willingness to buy LBC, yields adequate fit properties (CFI $=0.945, \chi 2 / \mathrm{df}=2.354, \mathrm{RMSEA}$ $=0.049$, NFI $=0.977$, AGFI $=0.975)$. The model statistically supports the proposed framework all the hypotheses were supported at the $p<0.001$ and 0.01 levels. CSBC significantly and positively influenced the willingness to buy $\operatorname{LBC}(\beta=0.36, p<0.001)$. EA significantly and positively influenced the willingness to buy LBC $(\beta=0.30, p<0.01)$. CPC significantly and positively influenced the willingness to buy $\operatorname{LBC}(\beta=0.27, p<$ $0.01)$.

Table 8 Hypotheses Results Summary

\begin{tabular}{|c|c|c|c|c|}
\hline Hypothesis & Effect & Statement & Estimate & Results \\
\hline H1 & Direct & CSBC is positively influences the willingness to buy LBC & $0.36 * * *$ & Supported \\
\hline $\mathrm{H} 2$ & Direct & $\begin{array}{l}\text { Emotional attachment has a direct positive effect on the } \\
\text { willingness to buy LBC }\end{array}$ & $0.30 * *$ & Supported \\
\hline $\mathrm{H} 3$ & Moderation & $\begin{array}{l}\text { Emotional attachment positively moderates the effect of } \\
\text { CSBC on willingness to buy CSBC to the extent that the } \\
\text { effect of CSBC on the willingness to buy LBC is stronger } \\
\text { when the emotional attachment is high }\end{array}$ & $0.38 * *$ & Supported \\
\hline $\mathrm{H} 4$ & Direct & $\begin{array}{l}\text { Conspicuous product consumption mediates positively the } \\
\text { relationship between CSBC and the willingness to buy } \\
\text { LBC }\end{array}$ & $0.27 * *$ & Supported \\
\hline H5 & Moderation & $\begin{array}{l}\text { Conspicuous product consumption positively moderates } \\
\text { the effect of CSBC on willingness to buy CSBC to the } \\
\text { extent that the effect of CSBC on the willingness to buy } \\
\text { LBC is stronger when the conspicuous product } \\
\text { consumption is high }\end{array}$ & $0.31 *$ & Supported \\
\hline
\end{tabular}

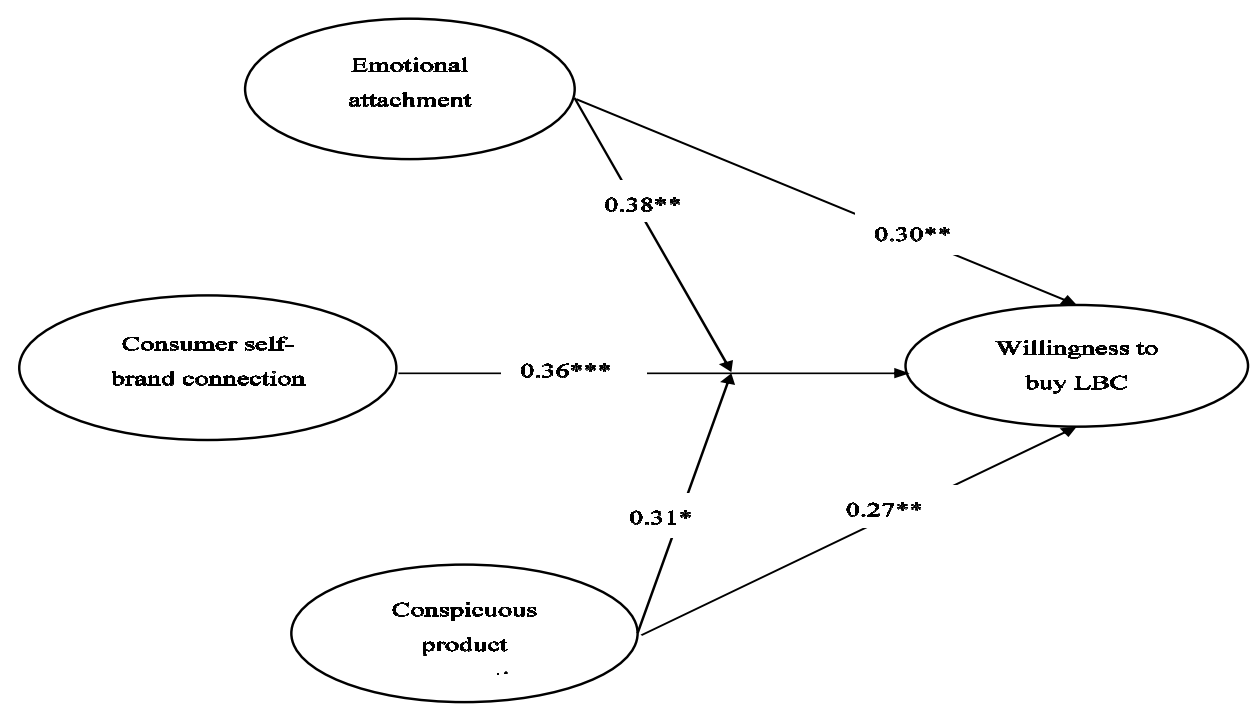

Note: $* p<0.05, * * p<0.01, * * * p<0.001$

Figure 1 Hypotheses Model Results with Moderators

\section{Discussion.}

Our results aligned with the work by Kaufmann, Petrovici, Filho, and Ayres (2016) that the effect of consumer self-brand connection on the willingness to buy LBC may vary according to how attachment is measured. The current study looked on the measures (CSBC, EA and CPC) to the extent to which a consumer has incorporated a brand into his or her self-concept which is psychological need. Thus, people engage in consumption behavior in part to construct their self-concepts and to create their personal identity, the reason which also agreed on the self-concept theory. Therefore, at this particular situation consumer might not see the importance of weather the product is original or not. The desire will be influenced on how their personal identity can be enhanced. This 
situation can be influenced with reference groups, the group which consumer associated with (Escalas \& Bettman, 2005). However, our results indicated that, producing increments in the emotional brand attachment level can increase the behavioral intentions of purchasing counterfeits opposite with Kaufmann, Petrovici, Gonçalves Filho, and Ayres (2016). The general conclusion is that consumers find sufficient value offered by the counterfeit luxury brand to prompt their purchase behavior which satisfies their inner self-concept as they have a connection to the brand and finally involved in LBC purchase.

\subsection{Theoretical contribution}

Considering how important the counterfeiting is for firms and economies, the study contributes to the creation and development of new knowledge in order to understand and mitigate these critical societal and economic phenomena. In this study the effect of CSBC, EA and CPC in the willingness to buy LBC was examined successful. The study was able to use suggestion from the competitive research and theory of self-concept on the effect of CSBC, EA and CPC in the willingness to buy LBC measurements and test the hypotheses. Since prior studies have described that consumer connects to brand to build its self-concept, the present study has added its contribution to the literature by moderate the relationship of interest with EA and CPC.

\subsection{Future research and limitations.}

The study based its investigation in foreigners who are living in Shanghai China only. Therefore, it's not presented the whole population, therefore we suggest future research should consider the same effect but to all people who are based in Shanghai to land into generalizability and robust findings.

\section{REFERENCES}

Ahuvia, A. C. 2005. Beyond the extended self: Loved objects and consumers' identity narratives. Journal of consumer research, 32, 171-184.

Amaldoss, W. \& Jain, S. 2005. Conspicuous consumption and sophisticated thinking. Management science, 51, 1449-1466.

Aron, A., Mashek, D., Mclaughlin-Volpe, T., Wright, S., Lewandowski, G. \& Aron, E. N. 2005. Including Close Others in the Cognitive Structure of the Self. In W. Stroebe \& M. Hewstone (Eds.), European review of social psychology, $15,101-132$.

Ashforth, B. E. \& Mael, F. 1989. Social identity theory and the organization. Academy of management review, $14,20-39$

Bagwell, L. S. \& Bernheim, B. D. 1992. Conspicuous consumption, pure profits, and the luxury tax. National Bureau of Economic Research. Working Paper No. 4163, 1-3

Bagwell, L. S. \& Bernheim, B. D. 1996. Veblen effects in a theory of conspicuous consumption. The American Economic Review, 349-373.

Baron, R. M. \& Kenny, D. A. 1986. The moderator-mediator variable distinction in social psychological research: Conceptual, strategic, and statistical considerations. Journal of personality and social psychology, $51,1173$.

Batra, R., Ahuvia, A. \& Bagozzi, R. P. 2012. Brand love. Journal of marketing, 76, 1-16.

Bearden, W. O. \& Etzel, M. J. 1982. Reference Group Influence on Product and Brand Purchase Decisions. Journal of Consumer Research, 9, 183-194.

Bowlby, J. 1979. The Making and Breaking of Affectional Bonds. London (Tavistock) 1979.

Browne, R. H. 1995. On the use of a pilot sample for sample size determination. Statistics in Medicine, 14, 19331940.

Chaplin, L. N. \& Roedder John, D. 2005. The Development of Self-Brand Connections in Children and Adolescents. Journal of Consumer Research, 32, 119-129.

Chaudhuri, H. R. \& Majumdar, S. 2006. Of diamonds and desires: understanding conspicuous consumption from a contemporary marketing perspective. Academy of Marketing Science Review, 11: 1-18.

Cooley, C. H. 1902. Human nature and the social order New York. C. scribner's sons.

Cordell, V. V., Wongtada, N. \& Kieschnick Jr, R. L. 1996. Counterfeit purchase intentions: role of lawfulness attitudes and product traits as determinants. Journal of Business Research, 35, 41-53.

Creswell, J. W. \& Creswell, J. D. 2017. Research design: Qualitative, quantitative, and mixed methods approaches, Sage publications.

Crutchfield, D. 2010. Celebrity endorsements still push product: why, in the era of social media, the rewards continue to outweigh the risks. Advertising, Age, (accessed July 15, 2020), [available at http://adage.com/article/cmo-strategy/marketing-celebrityendorsements-push-product/146023.

Dodds, W. B., Monroe, K. B. \& Grewal, D. 1991. Effects of price, brand, and store information on buyers' product evaluations. Journal of marketing research, 28, 307-319.

Dwivedi, A., Johnson, L. W. \& Mcdonald, R. E. 2015. Celebrity endorsement, self-brand connection and 
consumer-based brand equity. Journal of Product \& Brand Management, 24, 449-461.

Eisend, M. \& Schuchert-Güler, P. 2006. Explaining counterfeit purchases: A review and preview. Academy of Marketing Science Review, 2006, 1-18.

Epstein, S. 1973. The self-concept revisited: Or a theory of a theory. American psychologist, 28, 404.

Escalas, J. E. 2004. Narrative processing: Building consumer connections to brands. Journal of consumer psychology, 14, 168-180.

Escalas, J. E. \& Bettman, J. R. 2003. You are what they eat: The influence of reference groups on consumers' connections to brands. Journal of consumer psychology, 13, 339-348.

Escalas, J. E. \& Bettman, J. R. 2005. Self-construal, reference groups, and brand meaning. Journal of consumer research, 32, 378-3

Firat, A. F. 1991. The consumer in postmodernity. ACR North American Advances in Consumer Research Volume 18, eds. Rebecca H. Holman and Michael R. Solomon, Provo, UT : Association for Consumer Research, 18: 70-76.

Fornell, C. \& Larcker, D. F. 1981. Evaluating structural equation models with unobservable variables and measurement error. Journal of marketing research, 39-50.

Gentry, J. W., Putrevu, S. \& Shultz, C. J. 2006. The effects of counterfeiting on consumer search. Journal of Consumer Behaviour: An International Research Review, 5, 245-256.

Gistri, G., Romani, S., Pace, S., Gabrielli, V. \& Grappi, S. 2009. Consumption practices of counterfeit luxury goods in the Italian context. Journal of Brand Management, 16, 364-374.

Gosline, R. a. R. 2009. The real value of fakes: Dynamic symbolic boundaries in socially embedded consumption, Harvard University.

Grisaffe, D. B. \& Nguyen, H. P. 2011. Antecedents of emotional attachment to brands. Journal of Business Research, 64, 1052-1059.

Grossman, G. M. \& Shapiro, C. 1988. Foreign counterfeiting of status goods. The Quarterly Journal of Economics, 103, 79-100.

Groth, J. C. \& Mcdaniel, S. W. 1993. The exclusive value principle: the basis for prestige racing. Journal of Consumer Marketing, 10, 10-16.

Hair, J., Black, W., Babin, B., Anderson, R. \& Tatham, R. 2013. Multivariate Data Analysis: Pearson Education Limited.

Hammerl, M. 2016. Attribution of symbolic brand meaning: the interplay of consumers, brands and reference groups. Journal of Consumer Marketing, 33, 32-40.

Han, H. \& Hyun, S. S. 2013. Image congruence and relationship quality in predicting switching intention: Conspicuousness of product use as a moderator variable. Journal of Hospitality \& Tourism Research, 37, 303-329.

Han, Y. J., Nunes, J. C. \& Drèze, X. 2010. Signaling status with luxury goods: The role of brand prominence. Journal of marketing, 74, 15-30.

Hanspal, S. \& Devasagayam, P. R. 2017. Impact of Consumers' Self-Image and Demographics on Preference for Healthy Labeled Foods. SAGE Open, 7, 2158244016677325.

Hayes, A. F. 2017. Introduction to mediation, moderation, and conditional process analysis: A regression-based approach, Guilford Publications. 